\title{
Football in Lusophone Africa ?
}

Nuno Domingos, Institute of Social Sciences, University of Lisbon

https://doi.org/10.1093/acrefore/9780190277734.013.805

Published online: 17 December 2020

\section{Summary}

Since the beginning of the 20th century, the game of football has spread across the territories of the Portuguese colonial empire in Africa-Angola, Mozambique, GuineaBissau, Cape Verde, and São Tomé and Príncipe-quickly becoming part of the daily life of main colonial cities. It was introduced by Portuguese settlers and by individuals of other nationalities; in particular, members of the English business diaspora. Religious missions and schools as well as migrant individuals from trade and labor networks were all agents in the expansion of the game which, since the first decades of the century, has become integrated into the leisure practices of different imperial territories through the formation of clubs, associations, and tournaments. Sports associations were the most mobilizing form of its integration in the Portuguese colonial empire. This network became more extensive in colonies that were significantly urbanized, more populated, had more dynamic economies, and that had more settlers, who increasingly became fans of the game and followed competitions in the newspapers and on the radio. The institutionalization of the game incorporated the discriminatory structure of the Portuguese colonial system. The logic behind official sports policies created by the Estado Novo regime (1933-1974), which until the early 1960s did not include natives (indígenas), was thus applied. And yet, Africans soon took over the game, creating their own clubs and competitions. Resistance to Portuguese colonialism forced political changes, which resulted in a war fought on three different fronts, but also in a gradual abandonment of official policies of racial discrimination. In the colonial football sphere, this opening, combined with the development of a professional market, led to the movement of African players first to colonial clubs, and then to metropolitan clubs, and even to the national team. The fame and talent of these players, especially Eusébio da Silva Ferreira, ultimately helped in disseminating official government propaganda of a multiracial empire.

Keywords: Portugal, football, colonialism, Mozambique, Angola, Cape Verde, Guinea-Bissau, São Tomé, racism, urbanization, popular culture

\section{Introduction: A Colonial Sportization Process}

Football was introduced into the Portuguese colonies in Africa during the first decades of the 20th century. This period, termed the "Third Colonial Empire," was characterized, decades after the independence of Brazil in 1822, by effective rule over the African colonies of Angola and Mozambique-fundamental axes of the Portuguese imperial project in the 20th century- 
Guinea-Bissau, Cape Verde, and São Tomé and Príncipe. ${ }^{1}$ In addition to its African colonies, Portugal had possessions in India-Goa, Daman, and Diu-and administered the territories of Macao and East Timor.

The scholarly works that have recently researched the history of football in Lusophone Africa and the relationship of the sport with colonial modalities of rule have raised many historical, theoretical, and methodological questions. Was football in the Portuguese colonies in Africa used to create bonds between the colonized and the colonizers, as Mangan suggested when referring to the British imperial context and the ideological effect of cultural bonds? ${ }^{2}$ For Mangan and other scholars, sports practices helped to instill faithfulness to imperial values within the broader framework of indirect rule policies. In the case of Portuguese colonies, the construction of this affinity is discussed in this article within the ideological mechanisms inherent in mass culture, and more explicitly, through the bonds created between African populations and Portuguese football clubs.

Regarding the case of Angola, Marcelo Bittencourt discusses a policy of cultural approximation that uses football as a positive experience and thus intentionally produces a bond. ${ }^{3}$ Augusto Nascimento argues that football was built by the colonial state in São Tomé as an arena to replace politics and establish a cultural identification, especially in the 1960s. ${ }^{4}$ Marcos Cardão and Malaia Santos stress the ideological use of African tours made by Portuguese clubs to the colonies. Cardão researches the political instrumentalization of Eusébio da Silva Ferreira, and both articles provide examples of how Luso-tropicalism captured the realm of popular culture. ${ }^{5}$ Regarding Mozambique, Domingos demonstrates how the state shaped the local football organization in order to obtain political gains. ${ }^{6}$

However, these policies were not linear. Contrary to a policy of cultural proximity, until the late colonial period, the state's sports policies replicated forms of racial and social discrimination, and local sporting organizations, with differences between territories, gave rise to a strongly racialized institutionalization process. While these discriminatory rationalities can be found in other colonial contexts, the Portuguese case stands out for its longevity. This formally racist system, which did not help to create bonds, was only slowly dismantled beginning in the 1960s, and in many cases, change was visible only in the law.

Changes in Portuguese policies were a direct result of international pressure arising from African decolonization and the need colonial administrations felt to react politically to the onset of colonial wars (in Angola in 1961, in Guinea in 1963, and in Mozambique in 1964). It was in this context that Portugal insisted on the exceptional nature of its colonial empire, supposedly characterized by the absence of racism, an argument that Luso-tropicalism theory put forth by Gilberto Freyre, a Brazilian sociologist, helped legitimize. ${ }^{7}$ The need for the Portuguese state to develop a policy of winning "hearts and minds" also had consequences on the ground, easing racial discrimination and making mobility and social interactions more fluid. ${ }^{8}$

Football played an auxiliary role in the reconfiguration of colonial ideology in this period. For the Portuguese state, the integration of blacks into national teams, as Gilberto Freyre had previously argued regarding Brazil, proved the existence of an integrating imperial culture. A few black and mestizo players, benefiting from the development of football's professionalization, were involved in a process of labor migration from the colonies to the metropole, which the state had made possible since 1949. Revealing their talent, African 
players like Matateu, Coluna, Vicente, Hilário, and especially Eusébio da Silva Ferreira, all coming from Mozambique, became dominant figures in Portuguese clubs and the national team in the 1960s. ${ }^{9}$ The prominence of African players in metropolitan football as well as on a global level, a direct result of the achievements of Lisbon's Benfica in the early 1960s and the Portuguese national team in the 1966 England World Cup, left important marks in the colonies. ${ }^{10}$ For instance, it strengthened the link between African populations and the main Portuguese clubs, a bond that continues to exist in the early 21 st century.

The transformations that colonial policies and ideologies underwent in the 1960s produced a lasting representation of the history of colonial football and created a particular narrative about life in the African colonies. But this representation obscures the history of football's development in the Portuguese colonies in Africa. More importantly, it conceals its dominant feature: the projection in sport of the features of a strongly stratified and racist society. Up until the transition in the 1960s, this practice was encouraged by the colonial state.

It is crucial, however, not to reduce the process of introduction and dissemination of football in the colonial Lusophone world to the limits of the political and institutional sphere. Beyond the scope of political history, the game needs to be interpreted as a medium through which some of the most important problems of colonial societies, as well as their aspirations, expectations, and conflicting models of behavior, were channeled.

The state did not have a monopoly over the introduction and dissemination of the game, nor did it control its forms of appropriation. Colonial newspapers repeatedly described an unruly urban spectacle, resulting in scenes of violence that threatened public order. ${ }^{11}$ But the game was integrated into the lives of local communities, helping them to structure and build relatively autonomous spaces. It also acquired a set of local meanings, understandable only in light of the development of colonial communities under colonial rule. Played in neighborhood streets and empty spaces, in schools, religious missions, workplaces, clubs, and associations, football became an "interactional material," a provider of social encounters in countless situations. ${ }^{12}$ In this other empire where informal relations endure in contexts less codified by the state or by established social norms, football was freer to reveal its ability to bring individuals together and overcome the barriers imposed by the colonial system. In some contexts, such as in São Tomé, this development was due to an insufficient number of whites necessary to organize separate teams and competitions. ${ }^{13}$ In the suburbs of Luanda and Lourenço Marques, football provided an opportunity for rare social exchanges, namely, between the children of poor whites and blacks. This flexibility was much less visible when the game was institutionalized. In the actual competitions and in public access to the pitches, the advent of segregated sports organizations was a defining feature. Focusing on the labor strategies of African players in these Lusophone African settings, Todd Cleveland's research represents the most recent effort to go beyond a strict political history. He reveals how these workers and players profited from the growth of a specific labor market and followed their itineraries between Africa and the metropole while detailing their initial social conditions, their ongoing strategies, and their process of adaption to these strategies.

The Portuguese colonies in Africa were diverse, and this diversity affected the game's development. ${ }^{14}$ Cape Verde and São Tomé were the only territories where the Portuguese did not impose an indigenato system. Cape Verde was an uninhabited territory upon the arrival of the Portuguese. In São Tomé, African populations had obtained special status that 
distinguished them from labor migrants arriving from other imperial regions. In Angola, Mozambique, and Guinea, according to the civilization standards determined by the Portuguese, a division between "native" (indígena) and "civilized" populations was introduced in the law and maintained until 1961-the indigenato system. So-called assimilated Africans, a category that applied to individuals who proved they were able to adopt a "European way of life"-by having a job and renouncing their customs, traditions, religious practices, and family standards-were included among civilized populations. This dual citizenship became a fundamental tool for organizing colonial daily life and projected itself on the development of a labor system, on the patterns of settlement of rural and urban spaces, and on the organization of leisure, specifically on the expansion of sport and football practices.

Despite the political unity given by imperial rules and structures, the type of colonization in each of these colonial territories resulting from specific social, economic, and demographic conditions led to different patterns of football development. These differences are an argument against the tendency to consider that the Portuguese colonial experience created a unique and homogeneous sporting pattern. Each of these colonial territories deserves a particular analysis, and their structural and historical differences prevent major extrapolations. This diversity in football's diffusion process reinforces the idea that there has not been a single Portuguese imperial sportization process evolving linearly under the direction of a set of centralized structures and ideas.

\section{Beginnings}

The expansion of football in the Portuguese colonies in Africa reproduced the dynamics of the game's globalization based on the dissemination and institutionalization of a universal version that framed and shaped the practice. Dependent only on a group of players and a makeshift ball, football spread more effectively than sports that required the purchase of specific equipment, the command of techniques, or access to specific spaces of performance. As in other African colonial contexts, football, the main catalyst of the sportization process, gave rise, with distinct rhythms, to a well-known set of linked phenomena: the creation of clubs and associations, the building of pitches, and the introduction of paid competitions that generated the dynamic of professionalization. ${ }^{15}$ Football became a primary element of urban leisure and supported a particular relationship between practice and consumption based on the mechanism of social representation. The institutionalization of sports clubs and associations, whose main activity was the development of football, fitted the needs of urban colonial societies. Among different populations, football played a role in promoting sociability and interdependence at different scales in streets, neighborhoods, workplaces and spaces of leisure, and in small and large cities.

In looking closely at the Portuguese African colonies, it is difficult to identify the moment when a group of pioneers organized the first football games. Similar to other colonial contexts, the social world of ports and railways, the interest shown by missionaries of different faiths and by teachers and military men, and the dynamics of associations and of migratory networks were central to this process of dissemination. ${ }^{16}$ In fact, many of the agents that introduced the game were not citizens of the Portuguese empire. As elsewhere across the world, British communities played a pioneering role in introducing and institutionalizing this modern version of football by organizing the first games, clubs, and 
competitions. Through the initiative of businessmen, clerks, and other agents, they developed the practice of tennis, sailing, rugby, cricket, polo, and football. ${ }^{17}$ Other colonial agents were also crucial to the expansion of football in these colonial territories. Many Africans started playing in Catholic missions, such as the missions of São José de Lhanguene, which formed its own club, and Santana da Munhuana, both in Lourenço Marques, as well as the mission of São Paulo in Luanda. Protestant and Muslim organizations also encouraged the practice of football across these colonial territories. ${ }^{18}$ Despite the subordinate role football had in Portuguese educational programs, it was widely played in schools, as schoolteachers deemed it the most accessible game because it did not require specific materials or techniques. The game was also disseminated through internal and external migratory circuits. Many Mozambican workers, for instance, were introduced to football in South African mines. ${ }^{19}$ Labor environments were also privileged arenas for the game's diffusion. In fact, football supported paternalistic labor management policies, as several companies organized internal football competitions and some participated in corporate championships. The railway companies in Angola and Mozambique even set up their own club networks spread across the territories.

The Portuguese colonial system gave to this colonial sportization process a powerful dimension of social and racial exclusion, fundamentally reflected in the relationship between state policies and the framework of sports clubs and associations. The official repertoires of Portuguese colonization conceived by the central state did not grant a specific function to football, unlike in the British Empire, for example. ${ }^{20}$ Closer to the French frame of reference, Portuguese sport policies, both metropolitan and colonial, favored physical education models ${ }^{21}$-especially Ling's method ${ }^{22}$-seen as the basis of national regeneration policies, and distrusted the popularity of football created from the bottom up. Since football was not considered an educational tool by the Estado Novo regime, the game was excluded from the activities of the institutions responsible for organizing sports in the colonies, the Portuguese Youth (Mocidade Portuguesa), a premilitary organization aimed at Portuguese youth and inspired by Italian fascist and German national socialist counterparts, established in 1936 in the metropole and in the colonies in 1939; and the Provincial Councils for Physical Education (Conselhos Provinciais de Educação Física), established in the different colonies after $1956{ }^{23}$

In contrast to physical education models, promoted in schools and in the military, in the government's view football lacked a scientific foundation, stimulated unruly competition, and encouraged conflict and violence. Formally, it was too spontaneous, leaving abundant room for self-recreation, unlike gymnastics exercises, vetted by scientists and educators. ${ }^{24}$

But even though the government disapproved of football for ideological reasons, football was nevertheless disseminated throughout colonial societies. Endorsed by different agents, the institutionalization of football in Portugal's African colonies became a dimension of local urban societies, often reproducing their discriminatory structures. The activity of football clubs touched on numerous dimensions of the social and political life of the colonial territories. For the colonial state, their activities were politically ambivalent. However, these clubs did not promote the physical practices desired by the Estado Novo doctrine, but as social organisms operating in the colonies, their functions required a comprehensive approach from the state. Early on, colonial administrations recognized that these cells, whether in large cities or small towns, fulfilled an important mission. In more isolated contexts, they promoted the stability of settlers; in large cities they promoted social integration through the creation of networks of mutual help. The associations' institutional networks conferred specific powers on 
local social structures: they empowered elites, they generated engagement, and they imposed a public presence announced by the media; they were also useful in reinforcing policies of indirect rule and nationalist propaganda. Football clubs' boards included members of the colonial elites-state officials, members of religious institutions, businessmen, and traders. Sponsored by local entrepreneurs, some clubs helped to develop sports professionalization by making it easier for players to find jobs.

The official institutions responsible for organizing physical practices in the colonies (the Portuguese Youth and the Provincial Councils of Physical Education) included only the socalled civilized population. According to colonial officials, natives, whose lives were ruled by custom, would be able to engage with modern sports only when they became assimilated. Their "natural" sports, such as hunting or wrestling, depended on a certain natural functionality, far from the logic of modern leisure. ${ }^{25}$ Local African populations were also barred from organizing any kind of association, including sports associations. Indeed, all individuals who, by virtue of their status, were under the Native Political, Civil and Criminal Statute of 1929 (the indigenato) had no political rights in relation to European institutions and had no opportunity, according to the Overseas Administrative Reform of 1933, to organize administrative bodies, though nothing was mentioned about their participation as athletes in the activity of sports clubs. But while the law did not prevent the indígenas from taking part in sports competitions organized by associations and clubs, the boards of these clubs often imposed a social and racial selection. And even without this filter, Africans were not expected to compete on teams composed of whites.

Another dimension of exclusion involving football's institutionalization was its gender component. From an official standpoint during the Estado Novo, while football was not advisable for men, it was unthinkable for women. More delicate exercises were recommended for women, the kinds of movements that never allowed physical contact, which was the great taboo of female sport. ${ }^{26}$ In this regard, the state legitimized and purified the typical social prejudices of a patriarchal society. For this reason, the development of women's football, both in the metropole and the colonies, was almost nonexistent. ${ }^{27}$ In the colonies, the main clubs did not have specific football sections for women. News of neighborhood games between teams of women competitors was a curiosity mentioned in the press and barely disguised the deep-rooted discrimination that persisted. The likely existence of informal games between women, or that included women, did not lead to an institutional recognition of the participation of women in clubs and competitions in the settler communities or in the competitions organized in other contexts.

\section{Institutionalizing Football}

The development of football in the Lusophone colonial settings depended on a wide associative network that promoted what the state called private sport. This network converted football into a celebrated public spectacle, which became the core of a growing urban popular culture. Informal games gave way to a more solid institutionalization process in the 1920s and 1930s when the majority of clubs, competitions, and associations were founded. In Angola, the Luanda Football League was created in 1914 (the Luanda Football Association in 1929); the Football Association of the Province of Mozambique in 1923 (from 1926 onward renamed the 
Football Association of Lourenço Marques); the African Football Association in 1924; and the São Tomé Foot-Ball Association in 1935-1936. The Guinea Bissau Football Association was created only in 1952, although clubs had been established at least since the late $1920 \mathrm{~s}^{28}$

Particularly after the establishment of the Estado Novo in 1933, colonial administrations strictly controlled and oversaw the activities of all kinds of associations, including football clubs. Indeed, the Overseas Organic Charter of 1929 and the Organic Charter of the Portuguese Colonial Empire of 1933 subjected the approval of the statutes of associations to the approval of the Governor General after consulting the respective permanent section of the Council of Government. The 1933 Overseas Administrative Reform gave the state a set of supervisory and coordinating powers over associations. In the colonies, these political and legislative structures were enforced by the Civil Administration services, which oversaw the Regional Recreation, Defense, Sport, and Study Associations. Councils and district administrations, police commissioners, the Portuguese Youth, and the Native Affairs Services enforced all these regulations.

Some of the most important settler clubs and associations were branches of metropolitan clubs, such as Sport Lisboa e Benfica, Sporting Clube de Portugal, Académica de Coimbra, or Clube de Futebol Os Belenenses. ${ }^{29}$ In the 1950s, with the arrival of increasing numbers of settlers, new branches of Benfica and Sporting spread across Angola and Mozambique. In several smaller cities, these clubs were the only institutional bodies organized by the settlers. The colonial network of these metropolitan clubs, their occasional African tours, and the media coverage of their achievements created a strong connection between colonial populations and a metropolitan sports narrative that expanded beyond the settler universe. In neighborhood matches in the suburbs of large cities, these clubs inspired the formation of informal teams, which adopted their names. Media coverage was important in the creation of this bond. ${ }^{30}$

Since the first decades of the century, local newspapers had sports sections, and in Angola and Mozambique, actual sports presses emerged. ${ }^{31}$ The local press covered colonial competitions, but also paid attention to the championships and clubs of the metropole. The same happened in regard to the radio. The Portuguese national broadcaster, Emissora Nacional, aired the metropolitan games to the colonies, while local radio stations, namely, the influential Rádio Clube de Moçambique, broadcast both colonial and metropolitan competitions.

The activities of football clubs helped to structure the settlers' existence and reinforced a colonizer identity. Especially in the period before World War II, colonial sports associations firmly replicated an imperial rhetoric. ${ }^{32}$ Football, however, also helped to produce the settlers' identity in a different way, this time as a means of disruption with the metropole. The discrimination of colonial teams in the metropolitan competitions led to a protest that fueled a proto-autonomist sentiment. The interchange between metropolitan and colonial football clubs was limited to participation in 1958 in the Portuguese Cup. When a few metropolitan clubs visited the colonies, the games they played with local teams resulted in reactions that at the same time expressed a white Portuguese identity and a Luso-African singularity, autonomous from metropolitan nationalism. In Luanda and Lourenço Marques, the games that involved home-born teams generated broad enthusiasm. ${ }^{33}$ 
Throughout the 20th century and until the independence of Portuguese colonies in Africa in the mid-1970s, the network of football clubs was the largest network of settler associations in the field, both in large cities and in small towns. This growth increased during the colonial wars, when the frequency of approval of football clubs' statutes by the colonial administrations rose. Sports activities were then a subtle way of inscribing Portugal's power on African ground.

\section{African Appropriations}

From the beginning of the 20th century, football practice and consumption spread through the hierarchy of colonial society, among mestizo elites, ethnic minorities such as the Chinese or Indians, and among the most underprivileged groups. This process of institutionalization produced an alternative type of leisure, which also included the organization of gatherings, parties, concerts, balls, and several others celebrations. As centers of different networks, these football clubs contributed to the consolidation of new communities. Most of these clubs' boards and leaders shared specific social, national, ethnic, religious, and statutory identifications. However, football's competitive nature generated a mechanism of exchange between groups that brought about a shared existence under new urban conditions.

In most of the African Portuguese colonies, members of an African petite bourgeoisie were crucial to the development of sports associations. In Mozambique's capital, Vasco da Gama and Atlético de Lourenço Marques were exclusively mestizo clubs. In Luanda, football fields were a place of negotiation between the settler population and strata of the creole petite bourgeoisie, who created their own clubs, such as Liga Angolana, Grémio Luso-Angolano, and later Clube Atlético de Luanda, founded against the racial discrimination imposed by Clube Naval. ${ }^{34}$ On special occasions such as official visits, these clubs often represented the "nonEuropean" world that had already been assimilated. In Cape Verde, the adoption of sports practices by the creole elites happened even earlier on the island of São Vicente, a situation not generalizable to the remaining islands. Clube do Mindelo was founded in 1904 and was dedicated mainly to gymnastics; in 1915, still in Mindelo, the African Cricket Club was created, followed by Grémio Desportivo Cabo-Verdeano in 1916 and Clube Desportivo Mindelense in 1922. In São Vicente, Sporting Clube de São Vicente was created in 1928, Clube Desportivo Derby in 1929, and Grêmio Desportivo Amarante in 1936; in Praia, Sport Club was created in 1919 and União Desportivo da Cabo Verde in $1926{ }^{35}$

The colonial system, especially from the 1920s, put the so-called filhos da terra [sons of the land] elites in a difficult situation, as they had to choose between the imperial civilization appeal, also expressed in involvement with sports, or resistance to the increasing racism of local societies. If, after the establishment of the Estado Novo, creating associations became the most effective mode of African political organization, the leadership of these associations, devoted primarily to football, granted individuals an additional status. Through these associations, these elites wanted to promote sports as evidence of their ability to become civilized, and because they lacked the conditions to practice other sports, football was the best tool to achieve that aim. But given the conflicting and passionate nature of sports rivalries, the development of local football soon disappointed the most idealistic of these 
elites. This was what happened with some leaders of the Lourenço Marques African petite bourgeoisie, who after endorsing football's civilizing potential, were frustrated with the disorderly behavior of suburban players and audiences. ${ }^{36}$

In Luanda, the local championship brought together clubs formed by whites, such as Benfica, Sporting, or FC Luanda, a mestizo club, Atlético, and the railway workers' club, Ferroviário do Bungo, where blacks played alongside poor whites. ${ }^{37}$ In Mozambique, the football championship, dominated by Ferroviário, Desportivo, Sporting, and 1. de Maio clubs for decades, included, with a few concessions, only white players, while the club formed by the Catholic Indians from Goa included Indo-Portuguese players. Exceptions to this pattern were circumstantial until the early 1960s.

Discrimination against African players and teams was variable, especially in intermediate and ambiguous spaces which were more autonomous or dependent on local negotiations and existed under Portuguese rule. Even in less exclusive contexts, however, the distance that separated the intermediate social strata, composed of mestizos, assimilated blacks, and poor whites, from the rest of the population was clear. In the case of São Tomé, the difference between the "city" clubs, already divided between the white clubs such as Benfica, the clubs of the African elite such as Sporting, and the peripheral clubs of the villages, or the "roça" clubs, composed of servants, was critical. ${ }^{38}$.

In Mozambique's capital, in reaction to the segregating character of the Lourenço Marques Football Association, a group of suburban clubs formed a football association in 1924, the African Football Association (AFA). ${ }^{39}$ The AFA clubs represented a social community of sorts. Among the members of the AFA were religious clubs-Muslim, Catholic, and Protestantneighborhood clubs, and workplace or factory clubs. Many of them had ties with the Grémio Africano de Lourenço Marques, a local association with its own press, controlled by a majority of mestizos, established in 1908, and critical of the Portuguese colonial system. Politically controlled after the Estado Novo came to power and closed down in 1959, the AFA stirred the social life of the Lourenço Marques suburbs by involving the community, promoting exchanges with South African associations, and creating a performative arena with a particular local aesthetic. $^{40}$

While in Lourenço Marques colonial discrimination created separate competitions, in Luanda racial differences were projected in the diverse racial composition of the clubs that participated in local championships. ${ }^{41}$ Clubs such as Sport Luanda e Benfica, Futebol Clube de Luanda, and Sporting Club de Luanda did not include black players until the 1950s, and before that they had few mestizos competitors. ${ }^{42}$ What the colonial press called the "native football championship" was taking place on the outskirts of Luanda, in the pitches of Boavista and Exposição-Feira. ${ }^{43}$ A journalist attending some of these suburban games in the early 1950s found a livelier and larger attendance than at the Coqueiros municipal stadium. Admission was free, many players played barefoot, the referee and linesmen were chosen from the public, and the games, although weak in the journalist's opinion, featured teams that had a sense of modern football, translated in the pitch by an accurate division of labor, separating defenders, midfielders, and attackers according to their skills and functions. The newspaper article had an assimilationist rhetoric that eulogized football as a means of moral orientation for young Africans, especially assimilated Africans toward whom the article was particularly aimed. 
For the colonial state, it was important to recognize the existence of institutions that organized African populations' lives, and above all, to identify their leaders and spokesmen. The colonial system stimulated the creation of African associations based on confined identities and separation from settlers' sports organizations. For colonial officers, the emergence of black, mestizo, and assimilated African associations as well as clubs based on ethnic, religious, or labor bonds helped to frame local societies and enabled policies of indirect rule, which were more dependent on the practical knowledge of local civil servants than on centralized repertoires of rule. But ensuring this goal required strict surveillance, since sports associations were possible platforms for a specific type of political militancy that could take advantage of football's ability to foster collective organization and activate phenomena of representation, protest, and mobilization.

Different voices, even in the censored media, used sports as a stage for protest against racial discrimination. ${ }^{44}$ During the Estado Novo, colonial authorities inspected several football clubs in an attempt to prevent any possible act of political subversion. In Mozambique, the local administration persecuted a few clubs suspected of infiltration by political movements and Protestant churches. Similar persecutions took place in Angola, where the Botafogo club was closed, and the Atlético Luanda Club, known in the 1960s as the "terrorist club" because some of its former players were leaders of the liberation struggle, was put under close surveillance. Included in the political biography of Amílcar Cabral, the leader of the liberation movement in Guinea and Cape Verde, is his role in the foundation of the Bissau Sports and Recreational Club in 1954, where anti-colonialist militants gathered. The state police closed the club shortly after its creation. ${ }^{45}$

\section{Football Growth Patterns}

Within each colonial territory, the development of football depended on such considerations as the degree of urbanization, the difference between urban and rural spaces, the number of settlers, colonial state policies and the actions of its different agents, the level of economic activity, and the exposure of local societies to human mobility and information. Angola and Mozambique saw the most significant concentration of and largest colonial projects from the second half of the 19th century, but especially during the 20th century and particularly after World War II. In 1960, Luanda and Lourenço Marques had, respectively, 219,000 and 181,000 inhabitants. In 1974, a year before independence, Luanda's population reached 569,000 and Lourenço Marques 439,000. ${ }^{46}$ The level of urbanization in these territories, the presence of an important settler population, and greater economic activity accompanied by increasing state investment ensured favorable conditions for the development of modern sports. But in spite of these signs of modernity, an effective administrative occupation did not cover much of the colonial territory under Portuguese rule. With a scarce settler population, reduced basic administration, and few traders and businessmen, São Tomé and Príncipe, Guinea, and Cape Verde were even more undeveloped. São Tomé's economy depended on the exploitation of cocoa and coffee monocultures. This colony was a destination for goods and (coerced) migrant workers coming mainly from Cape Verde and Angola, and its poor degree of urbanization influenced the development of sports practices. Guinea, in turn, was one of the last territories to be "pacified" by the Portuguese. The physical conditions of the territory made colonization difficult and its economic potential was limited. Finally, the ten Cape Verdean islands required 
a detailed look at the archipelago, but the territory offered little grounds of interest for colonial exploitation, presenting adverse physical and climatic conditions for economic development, which justified its strong emigration pattern. ${ }^{47}$

Despite these differences, sports clubs, predominantly dedicated to football, comprised the majority of colonial associations. In Angola, of the 135 associations registered by the Statistical Yearbook in 1972, ninety-nine were dedicated to sport (twenty-four were of a recreational nature and twenty-one were considered mixed). Their geographical distribution confirmed a pattern of urban diffusion: Luanda had thirty-three associations, Benguela nineteen, Huambo sixteen, Bié ten, and Moxico and Huíla nine each. ${ }^{48}$ Membership in these associations grew with an increase in settlers. ${ }^{49}$ In Mozambique, data from 1967 revealed the existence of 233 associations, of which 157 were dedicated to sports (67 percent); 112 had as their main activity the promotion of football, which accounted for 71.3 percent of the associations dedicated to sports and 48 percent of the total associations compiled. ${ }^{50}$ Most of these associations were formed in the largest cities: Lourenço Marques and Beira. ${ }^{51}$

In Guinea, São Tomé, and Cape Verde, the sportization process took place at a necessarily different pace. Material and human conditions in São Tomé and Guinea, poorly urbanized areas with a small number of settlers, were not favorable for the expansion of football. In São Tomé, between 1968 and 1973, the number of sports groups ranged from seven to nine, and the number of members between 1,751 and 2,$362 ;{ }^{52}$ in 1968, there were 450 athletes recognized by statistics (249 playing football), and in 1973, 253 (143 playing football). ${ }^{53}$ In Guinea, at least nine sports associations existed in $1955 .^{54}$ In 1956, 511 members of clubs and associations were registered, a number that grew to 782 in 1958; 138 athletes played football in 1958 (fifteen practiced basketball, forty-nine volleyball, fifteen athletics, and twelve tennis). By 1973, the number of clubs had fallen to eight, comprising 1,328 members (869 of them in Bissau). ${ }^{55}$ The territory had five football pitches, four tennis courts, and four volleyball courts, and sixty-two football games were held, thirty-four of which were in Bissau and forty of which had paid entries, with 28,928 tickets sold or distributed. In 1933, the Cape Verde Archipelago already had twenty associations, ten of which were dedicated to sports (two in São Tiago and Praia, six in São Vicente and Mindelo, and two in Santo Antão and Ribeira Grande). ${ }^{56}$ Six years later, the sports associations comprised three-quarters of the associations (fifteen of twenty). Seven clubs were based in São Vicente, two in Ribeira Grande, two in Fogo, and four in Praia. Of their 2,159 members, 1,484 belonged to sports associations, 1,311 of whom were Africans from Cape Verde. ${ }^{57}$

\section{Football, Politics, and Urban Modernization in the Late Colonial Period}

In the late colonial period, the segregated structure of the football organization became more problematic. If, until the mid-1950s, the state considered that the creation of sports associations in large cities led to social integration that worked through the reinforcement of boundaries between groups, the African processes of decolonization and the advent of the colonial wars uncovered the racial character of this system. Progressively, colonial policies tried to implement a Luso-tropical approach. In Mozambique and Angola in the early 1950s, a concern about the place of African elites in this sporting universe was already present. In Lourenço Marques in 1952, two mestizo clubs, Atlético and Vasco da Gama, began to compete in the white league. In 1953, the president of the Luanda Football Association recommended 
the creation of a second division of the local championship "aimed at regulating the lives of the numerous clubs in the suburban area of the city." 58 This competition would include only clubs led by assimilated Africans (Bungo, Malhoas, Vasco da Gama, Ok Clube, Canaxixe, Vila Clotilde, Oeste, and ASA). ${ }^{59}$ In both Mozambique and Angola, suburban championships continued to take place outside formal platforms.

An effective integration of suburban clubs into official competitions only occurred in the transition to the 1960s. In the Mozambican capital, the administration closed down the AFA in 1959 when Portugal sought to eliminate all evidence of institutionalized colonial racism. This process stimulated the movement of players, and the football clubs' need for talent eventually promoted a social mobility that challenged rigid conceptions of social stratification.

But often the metropolitan state and colonial administrations did not operate in unison. In 1965, Angola's Provincial Council of Physical Education asked the central state for some restraint in enforcing legislation that required athletes who were members of sports federations to hold a fourth-grade school diploma. ${ }^{60}$ Angola's Provincial Secretary, José Pinheiro da Silva, argued that: “. . .the greater number of players of the so-called suburban clubs . . . the majority of which is made up of modest native workers, servants and factory workers, has shown that there is once again a need for tolerance. . ." because it was important to "cherish modest clubs."61

Still, despite these internal contradictions and the settlers' resistance to social and political change, with the colonial wars conditioning all overseas policies, football participated in the broader dynamics of winning hearts and minds. The role models given by African footballers playing in the metropole represented, from the regime's perspective, a multiracial and integrated Portugal. Best supported by archival sources, the case of Angola shows how football was an element present in the policies of psychosocial action, namely, the propaganda made in the slums by the native language radio broadcaster (Voz de Angola) and by the newspaper A Tribuna dos Musseques. ${ }^{62}$ In Mozambique, the largest local radio station, Rádio Clube de Moçambique, increased its native language broadcasts. One of the dimensions of these programs dedicated to local African populations was the transmission of football games, which also included games involving suburban teams.

On the eve of the April 1974 coup that overthrew the Estado Novo and paved the way for a swift process of decolonization, football was intensely present in the urban life of these territories. In many Portuguese colonial cities, football became not only a cherished sport, but also a social idiom of contact that promoted social interdependencies between urban populations. The appropriation of football was an element of Africans' relationships with a set of modern and urban social habits. The colonial power sought to use this to its advantage. Indeed, if state policies strengthened the bonds between metropolitan football clubs and local populations in the late colonial period, these clubs were also platforms for African competence, social representation, and everyday social practices in urban contexts. This perspective warns against reducing African players and African football consumers' social itineraries to the outcome of the political intentions of the Portuguese colonial state.

Moreover, it prevents an explanation of the current interest of the inhabitants of the former Portuguese colonies for Portuguese football clubs either as concrete evidence of the exceptionality of Portuguese colonialism or as the perverse result of a neocolonial project of rule that was initially driven by the colonial state's policies. 
Beyond the political forms of instrumentalization, other aspects defined the relationship local populations had with the game. The labor mobility that some black and mestizo players experienced in the late colonial period was unique in the colonial labor structure. If football clubs were traditionally instances of colonial discrimination, their relative openness after the late 1950s led them to become institutions through which blacks and mestizos could reach the highest level of public recognition, both in the colonies and in the metropole. This material and symbolic promotion gave football clubs a unique status among colonial institutions, as in practice they became a means to promote African talent and thus to represent populations historically segregated and discriminated against by Portuguese institutions.

\section{Discussion of the Literature}

Scholarship on football and sport in the Portuguese colonial context is relatively recent. Some works focusing on Portuguese colonialism, produced during or after the colonial period, make occasional references to this topic. ${ }^{63}$ In studies dealing with the formation of Portuguese nationalism, in turn, some references are made to the propagandistic uses of players coming from the colonies. ${ }^{64}$

However, as an autonomous theme, the study of football in the Portuguese empire only started roughly a decade ago, in the 2010s. Noteworthy in this context was the initiative of a group of researchers based in Rio de Janeiro. In 2010, these scholars organized a conference in Riothe International Symposium on Sport, Colonialism and Post-colonialism in PortugueseSpeaking African Countries-during which the topic was first addressed as a thematic unit. During this meeting, organized by Victor Andrade de Melo, Marcelo Bittencourt, and Augusto Nascimento, papers on Cape Verde (Melo), Angola (Andrea Marzano), São Tomé (Nascimento), and Mozambique (Nuno Domingos) were presented. After this initial stage, other meetings were regularly organized, almost always involving the same group of researchers. The effort to organize meetings and seminars was complemented by a set of editorial initiatives in journals-most of them resulting from the conferences-but additionally by two book collections coordinated by Victor Melo. ${ }^{65}$ Aside from edited books, monographs on Cape Verde (Melo) and São Tomé (Nascimento) and a group of texts on the Mozambican case (Domingos) have been published. ${ }^{66}$ In 2012, Domingos published his doctoral dissertation on football and colonialism in Mozambique in Portuguese. ${ }^{67}$ The historian Marcos Cardão, in his book on colonialism and popular culture, also investigated the role football had in the dissemination of Luso-tropicalism. ${ }^{68}$.

Much of this initial publishing effort on the history of football in the Portuguese colonies was confined to the Portuguese language circuit. The exceptions were the publication of a chapter by Gary Armstrong in the edited volume, Football in Africa, coordinated by Armstrong and Giulianotti, which reproduced and interpreted an interview by the author with the Mozambican player Eusébio da Silva Ferreira, a few journal articles by Domingos, and the English version of his monograph Football and Colonalism: Body and Popular Culture in Urban Mozambique. ${ }^{69}$ A recent work by historian Todd Cleveland, Following the Ball. The Migration of African Soccer Players across the Portuguese Colonial Empire, 1949-1975, focuses on the labor trajectories of African players to metropolitan Portugal during the colonial period. ${ }^{70}$ In 2018, the publication of a special issue in the International Journal of Sport History, devoted to sport in the Portuguese colonial context, brought the works of Melo, Marzano, Bittencourt, 
and Nascimento to an English-speaking audience and also included an article about Eusébio da Silva Ferreira by Marcos Cardão. ${ }^{71}$ In the past two years (2019-2020), new articles and special volumes, such as the recent issue in the journal Lusotopie on nationalism and sport in the Portuguese context, reinforced knowledge on this theme. ${ }^{72}$ This scholarship helped to create a research object that allows for historical comparisons, both between the Portuguese colonies and between the former and other imperial contexts. Moreover, it challenged Lusotropicalism nationalist discourse that survived the end of the empire and obscured the discriminatory foundations that defined football's institutional incorporation in colonial environments.

Some critical tensions intersect this bibliography. Probably the most relevant opposes a political history of football's development in the colonial Lusophone spaces to the historical approaches that aim to understand football's uses and functions within the process of colonial modernization, and the strategies, views, and expectations of the populations involved in this process. Most often these two perspectives imply the use of different theoretical and methodological tools. While it is clear that the state used football politically, one can wonder about the limits of this interpretation and whether it does not encapsulate in the perimeter of an institutional political history a phenomenon that is by far more multidimensional. If the colonial state used football's popularity, this institutional dynamic cannot alone account for the ways settlers and African populations engaged with the game. Despite the discriminatory colonial framework, football's intrinsic characteristics promoted ties among different strata of colonial populations. This happened through the actual practice of the game but mostly through the mechanism that turned football culture into a common social idiom which fitted well with the demands of urban life. In the colonies, the clubs, their stars, and performances were part of a shared knowledge that proved useful to promote broader social interactions going beyond closed identities. In order to fully understand this involvement with football, research must bring to light the active role of local populations in the strategic appropriation of football, both as performers and consumers. ${ }^{73}$

\section{Primary Sources}

Many of the primary sources directly connected to this subject are located in Portugal. They deal mostly with the policies of the metropolitan colonial state. As the regulation of sports practices in the colonies involved different institutions, relevant materials are located in diverse archival collections. The Arquivo Histórico Ultramarino (Lisbon, Portugal) is the main center of this information, and among its different fonds, the fonds of the Direção Geral de Educação is especially important. ${ }^{74}$ Other relevant documents can be found in the archival boxes of the fonds of the Agência Geral do Ultramar. Other archives detailing colonial policies of propaganda and political surveillance are also important, namely, the fonds of the Gabinete dos Negócios Políticos, currently held at the Arquivo HistóricoDiplomático in Lisbon; the fonds of the Portuguese Secret Policie (PIDE), the fonds of the Serviços de Centralização e Coordenação de Informações (Angola and Mozambique), and the Secretariado Nacional de Informação, all held in the Arquivo Nacional da Torre do Tombo (Lisbon). ${ }^{75}$

The fonds held in the former colonies also contain extremely valuable information. ${ }^{76}$ Because of the obvious similarities in the structures of the diverse colonial administrations, the archival organization of the records held at the Arquivo Histórico de Moçambique in Maputo may provide a general overview about the possible archiving processes of the records held in the other former Portuguese territories. In Luanda, it is much harder to locate these archival collections. In the Arquivo Histórico de Moçambique, the fonds of the Direcção dos Serviços de Administração 
Civil contains information on local clubs and associations, but also on the official institutions that oversaw sports practices, such as the Mocidade Portuguesa de Moçambique. ${ }^{77}$ When initially researching archives in Mozambique, the author discovered the important archive of the local Conselho Provincial de Educação Física (Provincial Council of Physical Education) was held in an informal space in the facilities of the Ministério da Juventude e Desportos de Moçambique (Youth and Sports Ministry), located in the Parque dos Continuadores in Maputo. In the Arquivo Histórico de Moçambique, the fonds of the Direcção dos Serviços dos Negócios Indígenas also contain information on the African clubs where the indígenas played. More sporadically, a few important documents on sports practices can be found in the fonds of the Governo Geral and of the local council, which, in the case of Lourenço Marques, is the fonds of the Administração do Concelho de Lourenço Marques, as well as the fonds of the Governo do Distrito de Lourenço Marques. Most of scholarship on football in former Portuguese colonies other than Mozambique did not cite primary sources found in colonial archives.

Apart from official archives, the universe of sports clubs and associations is the most interesting and by far the most unexplored. One the reasons for this is that clubs simply did not keep records or they were either destroyed or abandoned. Some clubs have since been closed; others did not find it important to maintain an archive, even if documents were stored in a specific location, most of the times inaccessible to the public. The author's attempts to find these archives in Maputo were fruitless, but this quest demands additional effort. The situation in the other former Portuguese colonies is in all likelihood very similar, contrary to that of Portuguese clubs. In the early 21st century, the archives of the former metropolitan clubs, those that were cherished across the colonial empire and that had local branches in numerous African cities, are still unexplored despite the fact that their records are organized.

The information held at the clubs' archives is extremely important to understand the depth of political instrumentalization during the Estado Novo regime, and especially in relation with the colonial world.

\section{Further Reading}

Armstrong, Gary. "The Migration of the Black Panther: An Interview with Eusébio of Mozambique and Portugal." In Football in Africa: Conflict, Conciliation and Community. Edited by Gary Armstrong and Richard Giulianotti, 247-268 (Hampshire, UK: Palgrave, 2004).

Bittencourt, Marcelo. "Sport and Politics in Angola's Final Colonial Years." International Journal of the History of Sport 35, no. 4 (2018): 356-373.

Cardão, Marcos. "A Star Is Born: Eusébio, Football, and Ideology in the Late Portuguese Empire." International Journal of the History of Sport 35, no. 4 (2018): 374-388.

Cleveland, Todd. Following the Ball. The Migration of African Soccer Players across the Portuguese Colonial Empire, 1949-1975. Athens, OH: Ohio University Press, 2017.

Coelho, João Nuno. A Equipa de Todos Nós-Nacionalismo, Futebol e Media. Porto, Portugal: Afrontamento, 2002.

Domingos, Nuno. Football and Colonialism: Body and Popular Culture in Urban Mozambique. Athens, OH: Ohio University Press, 2017.

Marzano, Andrea, "Bodily Practices and Colonialism: Sport and Physical Culture in Luanda, 1860-1930." International Journal of the History of Sport 35, no. 4 (2018): 314-334.

Melo, Victor Andrade de. Jogos de identidade: o esporte em Cabo Verde. Rio de Janeiro, Brazil: Apicur, 2011. 
Melo, Victor Andrade de. "Different Faces of Colonialism: Sport in Cape Verde and Portuguese Guinea." International Journal of the History of Sport 35, no. 4 (2018): 296-313.

Nascimento, Augusto. "Football and Colonialism in São Tomé." International Journal of the History of Sport 35, no. 4 (2018): 335-355.

Nascimento, Augusto, Marcelo Bittencourt, and Victor Andrade de Melo, eds. Mais do um Jogo: o esporte e o continente africanos. Rio de Janeiro, Brazil: Apicuri, 2010.

Pinheiro, Francisco Manuel. "Sport and Press in the Portuguese Colonies of Africa: Origins and Historical Perspectives.” Conhecimento Online, 2, no. 9 (July-December 2017): 3-13.

\section{Notes}

1. Gervase Clarence-Smith, The Third Portuguese Empire (1825-1975): A Study in Economic Imperialism (Manchester, UK: Manchester University Press, 1985).

2. James Anthony Mangan, The Cultural Bond: Sport, Empire, Society (London: Frank Cass, 1992), 3-4.

3. Marcelo Bittencourt, "Sport and Politics in Angola's Final Colonial Years," International Journal of the History of Sport 35, no. 4 (2018): 366, 367.

4. Augusto Nascimento, "Football and Colonialism in São Tomé," International Journal of the History of Sport 35, no. 4 (2018): 335-336, 344.

5. Marcos Cardão, "Peregrinações exemplares: as Embaixadas Patrióticas dos Clubes metropolitanos ao 'ultramar português," in Esporte e Lazer em África. Novos olhares, ed. Augusto Nascimento, Marcelo Bittencourt, Nuno Domingos, and Victor Andrade de Melo (Rio de Janeiro, Brazil: 7Letras, 2013); João Malaia Santos, "Os Leões em África: futebol e política no Império Colonial Português (1954)," Estudos Históricos 32, no. 68 (2019): 589-608; and Marcos Cardão, "A Star Is Born: Eusébio, Football, and Ideology in the Late Portuguese Empire," International Journal of the History of Sport 35, no. 4 (2018): 374-388.

6. Nuno Domingos, Football and Colonialism: Body and Popular Culture in Urban Mozambique (Athens, OH: Ohio University Press, 2017).

7. Gilberto Freyre, Aventura e rotina: Sugestões de uma viagem a procura das constantes portuguesas de carácter e acção (Lisbon, Portugal: Edicões Livros do Brasil, 1954); and Gilberto Freyre, Um brasileiro em terras portuguesas: Introdução a uma possível Lusotropicalogia (Lisbon, Portugal: Edições Livros do Brasil, 1954).

8. Warwick Anderson, Ricardo Ventura Santos, and Ricardo Roque, Luso-Tropicalism and Its Discontents: The Making and Unmaking of Racial Exceptionalism (London: Berghann, 2019), 102-134.

9. Domingos, Football and Colonialism; and Todd Cleveland, Following the Ball: The Migration of African Soccer Players across the Portuguese Colonial Empire, 1949-1975 (Athens, OH: Ohio University Press).

10. João Nuno Coelho, A Equipa de Todos Nós: Nacionalismo, Futebol e Media (Porto, Portugal: Afrontamento, 2002).

11. Domingos, Football and Colonialism.

12. Erving Goffman, “The Interaction Order," American Sociological Review 48, no. 1 (February 1983): 11.

13. Nascimento, "Football and Colonialism in São Tomé," 335-355. 
14. Among other authors, for the history of Angola, see Gerald Bender, Angola Under the Portuguese: The Myth and the Reality (Berkeley, CA: University of California Press, 1978); Isabel Castro Henriques, Território $e$ Identidade: A Construção da Angola Colonial (Lisbon, Portugal: Universidade de Lisboa, 2004); on Mozambique, see Malyn Newitt, A History of Mozambique (Bloomington: Indiana University Press, 1995); Allen Isaacman and Barbara Isaacman, Mozambique: From Colonialism to Revolution, 1900-1982 (Boulder, CO: Westview Press, 1983); and Jena Maries, Penvenne, African Workers and Colonial Racism: Mozambican Strategies and Struggles in Lourenço Marques, 1877-1962 (London: James Currey, 1995); on São Tomé, see Augusto Nascimetno, Poderes e Quotidiano nas Roças de S. Tomé e Príncipe de finais de oitocentos a meados de novecentos (Lousã, Portugal: Tipografia Lousanense, 2002); and Gerhard Seibert, Comrades, Clients and Cousins: Colonialism, Socialism and Democratization in São Tomé and Príncipe (Leiden, The Netherlands: Brill 2006); on Guinea Bissa, see Carlos Lopes, Ethnie et rapports de pouvoir en Guinée-Bissau (Geneva, Switzerland: Institut Universitaire d'Études du Développement, 1983); René Pélisier, História da Guiné: Portugueses e africanos na Senegâmbia (1841-1936) (Lisbon, Portugal: Estampa, 1988); on Cape Verde, see Richard A. Lobban Jr., Cape Verde: Crioulo Colony to Independent Nation (London: Routledge, 2018).

15. Peter Alegi, Laduma: Soccer, Politics and Society in South Africa (Natal, South Africa: University of Kwazulu-Natal Press, 2004); Phyllis Martin, Leisure and Society in Colonial Brazzaville (Cambridge, UK: Cambridge University Press, 1995); Laura Fair, Pastimes and Politics, Culture, Community, and Identity in Post-Abolition Urban Zanzibar (Oxford: James Currey, 2001), 189-194; Bea Vidacs, Visions of a Better World: Football in the Cameroonian Social Imagination (Berlin: Lit Verlag, 2010); and Norbert Elias and Eric Dunning, The Quest for Excitement: Sport and Leisure in the Civilizing Process (Oxford: Basil Blackwell, 1986).

16. Martin, Leisure and Society; Fair, Pastimes and Politics; Alegi, Laduma; and Armstrong and Giulianotti, Football in Africa.

17. In the early 20th century in Mozambique, they founded the Athletic Club, Beira Amateur Sports Club, Beira Railway Athletic Club, Beira Golf Club, and the Lourenço Marques Lawn Tennis Club. In São Tomé, the Submarine Communications Cable officials developed some of the first sports organizations, and in 1912, the English were also linked to the formation of one of the first local clubs, the Sport Club de São Tome. In Angola, British officials from the Submarine Communications Cable played a similar role, organizing informal competitions at least since 1897. In Cape Verde, several English companies, while exploring the strategic position of the port of Mindelo, promoted sports practices from the mid-19th century and founded the East India Club, Saint Vincent Golf Cape Verde Island, and the Lawn Tennis Club.

18. In the suburbs of Mozambique's capital, Muslim communities founded Mahafil Isslamo in 1915, the oldest club in the country that is still active today, and Atlético Mahometano in 1929.

19. Patrick Harries, Work, Culture, and Identity: Migrant Laborers in Mozambique and South Africa, c. 1860-1910 (Portsmouth, NH: Heinemann, 1993).

20. See Brian Stoddart, "Sport, Cultural Imperialism, and Colonial Response in the British Empire," Comparative Studies in Society and History 30 (1988): 649-673; Harold Perkin, "Teaching the Nations How to Play: Sport and Society in the British Empire and Commonwealth," in The Cultural Bond: Sport, Empire, Society, ed. James Anthony Mangan (London: Frank Cass, 1992); Anthony Kirk-Green, "Imperial Administration and the Athletic Imperative: The Case of the District Officer in Africa," in Sport in Africa, Essays in Social History, ed. William J. Baker and James Anthony Mangan (New York: Africana, 1987), 81-113; and Allen Guttman, Games and Empires: Modern Sports and Cultural Imperialism (New York: Columbia University Press, 1994).

21. Bernardette Deville-Danthu, Le Sport en Noir et Blanc, Du sport colonial au sport africain dans le anciens territoires français d'Afrique occidentale (1920-1965) (Paris: L'Harmattan, 1997); see Luís Miguel Carvalho, "Explorando as transferências educacionais nas primeiras décadas do século XX," Análise Social 
40, no. 176 (2005): 499-518; António Gomes Ferreira, "O ensino da Educação Física em Portugal durante o Estado Novo," Perspectiva: Revista do Centro de Ciências da Educação 22 (July-December 2004): 197-224; and Nuno Domingos, "Building a Motor Habitus: Physical Education in the Portuguese Estado Novo," International Review for the Sociology of Sport 45 (2010): 23-37.

22. See Gertrud Pfister, “'Cultural Confrontations': German Turnen, Swedish Gymnastics and English Sport, European Diversity in Physical Activities from a Historical Perspective," Culture, Sport and Society 6, no. 1 (Spring 2003): 61-69.

23. Law 2083 (June 15, 1956, Diário do Governo, no. 122, 1a série) was published in the Boletim Oficial of all colonial territories on different dates (Mozambique: DL no. 1670, May 4, 1957; São Tomé, DL no. 193, December 26, 1957; Guinea, DL no. 1385, August 30, 1958; Cape Verde, DL no. 1711, July 11, 1959; Macau, DL no. 1470, November 5, 1960; Angola, DL no. 3208, January 17, 1962. In Macau, the Provincial Council of Physical Education replaced the Conselho dos Desportos (Sports Council), created in 1955.

24. Domingos, "Building a Motor Habitus."

25. On traditional African sports, see John Blacking, "Games and Sport in Pre-Colonial African Societies," in Sport in Africa: Essays in Social History, ed. William J. Baker and James Anthony Mangan (New York: Africana, 1987): 322.

26. Inês Brasão, Dons e Disciplinas do Corpo Feminino (Lisbon, Portugal: Deriva/Outro Modo, 2016).

27. Inês Brasão. “Improváveis simetrias: um retrato do futebol feminino," in A Época do Futebol, ed. José Neves and Nuno Domingos (Lisbon, Portugal: Assírio e Alvim, 2004).

28. The União Internacional Desportiva de Bissau was founded in 1929 and the Atlético Clube de Bolama in 1930; Victor Andrade de Melo, "Different Faces of Colonialism: Sport in Cape Verde and Portuguese Guinea," International Journal of the History of Sport 35, no. 4 (2018): 301.

29. In Angola, the first were Sporting de Luanda (1920) and Sport Luanda and Benfica (1922). In Mozambique, the first were Sport Lisboa e Beira (1916), Sporting de Lourenço Marques (1920, now called Maxaquene) and Grupo Desportivo de Lourenço Marques, then a branch of Benfica (1921). In São Tomé, Sporting Clube, founded in 1940, later became a subsidiary of Sporting Clube de Portugal. In the 1960s, branches of Benfica and Sporting also existed on the small island of Príncipe. In Guinea, Benfica's branch, Sport Lisboa e Bissau, alongside Sporting Club de Bissau and Bissau International Sports Union, led the city's sports' movement. In Bolama, a Benfica branch, Sport Lisboa e Bolama, existed at least since 1935.

30. Francisco Manuel Pinheiro, "Sport and Press in the Portuguese Colonies of Africa. Origins and Historical Perspectives," Conhecimento Online 2, no. 9 (July-December 2017): 3-13.

31. The number of sports newspapers included Sporting (Luanda, 1922), A Semana Desportiva (Lourenço Marques, 1922), Desportos (Luanda, 1923), Angolana (Luanda, 1929), Angola Desportiva (Luanda, 1930), Atlético (Mossamedes, 1931), Desportine (Luanda, 1934), Eco dos Sports (Lourenço Marques, 1938), Goal (Cape Verde, 1944), Goal em Angola (Luanda, 1948), and O Estádio (Lourenço Marques, 1955). See Pinheiro, "Sport and Press in the Portuguese Colonies of Africa."

32. See A Colónia de São Tomé, Jornal comemorativo do ano XIII da revolução nacional (May 28, 1939). Número comemorativo do aniversários dos CDLXXI anos do descobrimento da Ilha de São Tomé do XIV aniversario do Sporting Club de S. Tomé (December 21, 1940); and Estatutos do Sport Lisboa e Bolama (Bissau, Guinea-Bissau: Imprensa Nacional da Guiné, alteração dos estatutos aprovados em 1929).

33. Domingos, Football and Colonialism, 37.

34. Andrea Marzano, "Bodily Practices and Colonialism: Sport and Physical Culture in Luanda, 1860-1930," International Journal of the History of Sport 35, no. 4 (2018): 314-334 and 320-324. 
35. Andrade de Melo, "Different Faces of Colonialism."

36. Domingos, Football and Colonialism, 105-112.

37. Bittencourt, "Sport and Politics," 356-373.

38. Nascimento, "Football and Colonialism in São Tomé," 340-343.

39. Domingos, Football and Colonialism.

40. Domingos, Football and Colonialism.

41. Marzano, "Bodily Practices and Colonialism," 322.

42. Bittencourt, "Sport and Politics," 360.

43. "Subúrbios de Luanda," Goal, May 24, 1950: 1-2. Included in the group of teams created in the musseques were Estoril Praia, Onze Bravos do Quinzan, o Lusitano, and Académica do Ambrizete.

44. Bittencourt, "Sport and Politics," 362-363.

45. Andrade de Melo, "Different Faces of Colonialism.".

46. Comparative data available at macrotrends <https://www.macrotrends.net/cities $>$.

47. Joel Serrão, ed., Nova história da expansão portuguesa, vol. 2, O império africano (1825-1890), ed. António Henrique de Oliveira Marques(Lisbon, Portugal: Estampa, 1998); Joel Serrão, ed. Nova história da expansão portuguesa, vol. 3, O império africano (1890-1930), ed. António Henrique de Oliveira Marques (Lisbon, Portugal: Estampa, 1998); Francisco Bethencourt and Kirti Chaudhuri, eds., História da Expansão Portuguesa, 5 vols. (Lisbon, Portugal: Círculo dos Leitores, 1999).

48. Anuário Estatístico de Angola (Luanda: Departamento de Estatística de Angola, 1973), 100.

49. In 1969, 43,442 individuals were members of associations; in 1970, there were 47,122 members; in 1971, 53,039; in $1972,58,657$; in 1973, 63,808. In 1973, 45,509 of the total of 63,808 members were active in sports associations. In 1973, more than half of these members lived in Luanda; from Anuário Estatístico de Angola (Luanda: Departamento de Estatística de Angola, 1970-1974); and Noronha Feio, Desporto e Política, ensaios para a sua compreensão (Lisbon, Portugal: Compendium, 1979), 90-97.

50. Anuário Estatístico de Moçambique (Lourenço Marques: Departamento de Estatística, 1968):105.

51. Feio, Desporto e Política.

52. Anuário Estatístico de São Tomé e Príncipe (São Tomé: Departamento de Estatística, 1969-1974). The evolution of the number of clubs and members of clubs in São Tomé was the following: 1968 (seven clubs and 1,751 members), 1969 (eight and 2,149), 1970 (nine and 1,629), 1971 (nine and 1,574), 1972 (nine and 2,134), and 1973 (nine and 2,326).

53. Anuário Estatístico de São Tomé e Príncipe. The evolution of the number of athletes and footballers in São Tomé was the following: 1968 (381 athletes, 120 footballers), 1970 (358 and 127), 1971 (350 and 150), 1972 (265 and 140), and 1973 (253 and 143).

54. Sport Lisboa e Bissau, Sporting Clube de Bissau, UDIB, Sport Bolama e Benfica, Clube Desportivo e Recreativo de Farim, Sport Clube de Bafatá, Clube Futebol os Balantas, Atlético Clube de Bissor, Clube Desportivo de Teixeira Pinto.

55. Three in Bissau, three in Bolama, and one in Bafatá, Farim, and Mansoa; Anuário Estatístico da Colónia da Guiné (Bissau: Serviços de estatística, 1947): 63.

56. Anuário Estatístico da Colónia de Cabo Verde (Cidade da Praia, Serviços de Estatística, 1933): 142-148.

57. Anuário Estatístico da Colónia de Cabo Verde (Cidade da Praia, Serviços de Estatística, 1939): 123

58. Goal, April 7, 1953, 1-2. 
59. Goal, July 22, 1953, 4.

60. Daniel Rogério Leite, Relatório de Actividades Desportivas do CPEF de Angola (Luanda, Angola: Fundo de Turismo e Publicidade, 1965).

61. Arquivo Histórico Ultramarino, Direção-geral de Educação Caixa 215, Secção C, Processo 10.1, Comum. Assunto Atletas. Processon 10, 10.1/2. Extensividade ao Ultramar do disposto no Artigo 22.. do DL 40 964, de 31 de Dezembro de 1956 (Exigências aos atletas de habilitações literárias). Letter from the Secretário Provincial de Angola, August 6, 1965.

62. Bittencourt, "Sport and Politics," 365-366.

63. See, for instance, Aurélio Rocha, Associativismo e Nativismo em Moçambique: Contribuição para o estudo das origens do nacionalismo moçambicano (1900-1940) (Maputo, Mozambique: Promédia, 2002).

64. José Cutileiro, “Os super portugueses: algumas notas sobre o Sport Lisboa e Benfica," Tempo e o Modo 25-26 (1965): 319-330; Coelho, A Equipa de Todos Nós; Rahul Kumar, A Pureza Perdida do Desporto: Futebol no Estado Novo (Lisbon, Portugal: Paquiderme, 2017); Ana Santos, Heróis Desportivos, estudo de caso sobre Eusébio: de corpo a ícone da Nação (Lisbon, Portugal: Instituto do Desporto de Portugal, 2004); and José Neves, "O eterno fado dos últimos 30 metros, nacionalismo e corpo," in A Época do Futebol: o jogo visto pelas Ciências Sociais, ed. José Neves and Nuno Domingos (Lisbon, Portugal: Assírio e Alvim, 2004).

65. See the special volume of Caderno de Estudos Africanos, "Em torno das práticas desportivas em África," 2013; Augusto Nascimento, Marcelo Bittencourt, Nuno Domingos, and Victor Andrade de Melo, eds., Esporte e lazer na África: Novos Olhares (Rio de Janeiro, Brazil: 7Letras, 2013); Augusto Nascimento, Marcelo Bittencourt, and Victor Andrade de Melo, eds., Mais do um Jogo: o esporte e o continente africanos (Rio de Janeiro, Brazil: Apicuri, 2010).

66. Victor Andrade de Melo, Jogos de identidade: o esporte em Cabo Verde (Rio de Janeiro: Apicur, 2011); Augusto Nascimento, Esporte e vez de política no São Tomé e Princípe (Rio de Janeiro, Brazil: 7Letras, 2013); and Nuno Domingos, As Linguagens do Futebol em Moçambique. Colonialismo e Cultura Popular (Rio de Janeiro, Brazil: 7Letras, 2015).

67. Nuno Domingos, Futebol e Colonialismo: Corpo e Cultura Popular em Moçambique (Lisbon, Portugal: Imprensa de Ciências Sociais, 2012).

68. Marcos Cardão, Fado Tropical: O Luso-Tropicalismo na Cultura de Massas (1960-1974) (Lisbon, Portugal: Unipop, 2015).

69. Gary Armstrong, "The Migration of the Black Panther: An Interview with Eusébio of Mozambique and Portugal," in Football in Africa: Conflict, Conciliation and Community, ed. Gary Armstrong and Richard Giulianotti (Hampshire, UK: Palgrave, 2004), 247-268; Domingos, Football and Colonialism, 478-494; Nuno Domingos, "Urban Football Narratives and the Colonial Process in Lourenço Marques," International Journal of the History of Sport 28, no. 15 (2011): 2159-2175; and Domingos, Football and Colonialism.

70. Cleveland, Following the Ball.

71. Marcos Cardão, "A Star Is Born.”

72. Nuno Domingos and Victor Pereira, "Sport et nationalismes. Pour une approche comparative dans l'espace de la Lusotopie," Lusotopie 18, no. 1 (2019): 119-141.

73. Cleveland, Following the Ball.

74. For the Arquivo Histórico Ultramarino, see http://ahu.dglab.gov.pt/ <http://ahu.dglab.gov.pt/>. 
75. For the fonds of the Gabinete dos Negócios Políticos, see https://actd.iict.pt/view/ actd:AHUMUd003 <https://actd.iict.pt/view/actd:AHUMUd003>; for the Arquivo Nacional da Torre do Tombo, see http://antt.dglab.gov.pt/ <http://antt.dglab.gov.pt/>.

76. The author is familiar only with the Arquivo Histórico de Moçambique.

77. For the Arquivo Histórico de Moçambique, see https://www.uem.mz/index.php/sobre-a-uem/unidadesorganicas/especiais/arquivo-historico-de-mocambique_<https://www.uem.mz/index.php/sobre-auem/unidades-organicas/especiais/arquivo-historico-de-mocambique $>$.

\section{Related Articles}

Sport History and Historiography

African Masculinities 